\title{
PERANAN PENGELOLAAN KELAS \\ DALAM MENGEMBANGKAN KETERAMPILAN MENULIS DI SMP MUHAMMADIYAH 1 MALANG
}

\author{
Meita Setianing Mulyadi ${ }^{1}$, Gigit Mujianto \\ ${ }^{1}$ Pendidikan Bahasa dan Sastra Indonesia Universitas Muhammadiyah Malang, Jalan Raya Tlogomas \\ 246 Malang, meitasm17@gmail.com \\ ${ }^{2}$ Pendidikan Bahasa dan Sastra Indonesia Universitas Muhammadiyah Malang, Jalan Raya Tlogomas \\ 246 Malang, gigit@umm.ac.id
}

\begin{abstract}
ABSTRAK
Penelitian ini bertujuan untuk mendeskripsikan bentuk peran pengelolaan kelas (manajemen kelas) yang diolah oleh guru dan peran guru dalam pengelolaan kelas di SMP Muhammadiyah 1 Malang. Pendekatan yang digunakan dalam penelitian ini adalah pendekatan deskriptif dan menggunakan jenis penelitian kualitatif. Data penelitian ini mencakup tentang bentuk dan peran guru dalam proses pengelolaan kelas. Sumber data yakni guru dan peserta didik kelas IX di SMP Muhammadiyah 1 Malang. Proses pengumpulan data dengan cara wawancara, dokumentasi, dan observasi langsung di dalam kelas. Teknik analisis data menggunakan teori John Afifi dan Padmono. Hasil dari penelitian ini menunjukkan (1) Bentuk pengelolaan kelas yang diolah guru guna mengembangkan keterampilan menulis. (2) Peran guru dalam pengelolaan kelas untuk mengembangkan keterampilan menulis pada pembelajaran Bahasa Indonesia.
\end{abstract}

Kata Kunci : pengelolaan kelas, peran guru

\begin{abstract}
This study aims to describe the form of the role of classroom management (class management) that is processed by the teacher and the role of the teacher in classroom management in SMP Muhammadiyah 1 Malang. The approach used in this study is a descriptive approach and uses qualitative research. This research data includes the form and role of teachers in the classroom management process. The data sources are teachers and class IX students in Muhammadiyah 1 Junior High School Malang. The process of collecting data by interviewing, documenting, and direct observation in the classroom. Data analysis techniques using the theory of John Afifi and Padmono. The results of this study indicate (1) The form of classroom management that is processed by the teacher to develop writing skills. (2) The role of the teacher in classroom management to develop writing skills in learning Indonesian.
\end{abstract}

Keywords: classroom management, teacher role

DOI: https://doi.org/10.31943/bi.v5i1.63

\section{How to Cite :}

Mulyadi, M. S. M. (2020). PERANAN PENGELOLAAN KELAS DALAM MENGEMBANGKAN KETERAMPILAN MENULIS DI SMP MUHAMMADIYAH 1

MALANG. Bahtera Indonesia; Jurnal Penelitian Bahasa Dan Sastra Indonesia , 5(1), 73-87. https://doi.org/10.31943/bi.v5i1.63 


\section{PENDAHULUAN}

Pendidikan merupakan suatu proses pembelajaran yang didampingi oleh seorang guru untuk melatih pengetahuan, keterampilan, dan kebiasaan orang-orang yang sedang menimba ilmu di sekolah ataupun di suatu lembaga pendidikan yang lainnya. Salah satu bentuk permasalahan dalam dunia pendidikan terutama di Indonesia adalah minimnya prosedur yang baik proses pembelajaran. Seyogiyanya dalam proses pembelajaran, peserta didik sangat diharuskan mendapatkan sebuah dorongan untuk meningkatkan kemampuan berpikir kreatif dari guru. Seperti halnya yang dikemukakan oleh Muhadjir (Mujianto, 2019) suatu lembaga pendidikan harus melaksanakan tiga fungsi. Pertama adalah fungsi untuk mengembangkan kreativitas dari peserta didik. Kedua yaitu berfungsi untuk memberikan nilai-nilai kepada peserta didik. Ketiga adalah seorang guru harus mampu untuk mengembangkan keproduktifan peserta didik dalam kegiatan pembelajaran. Dari ketiga fungsi tersebut, peran utama seorang guru adalah agar semua dapat terlaksana sesuai dengan telah yang direncanakan.

Seorang guru memiliki peran penting yaitu pada proses pembelajaran Bahasa Indonesia. Guru harus membantu peserta didik untuk mencapai kompetensi, misalnya pada bidang pengetahuan, sikap, dan keterampilan. Ketiga kompetensi ini agar terlaksanakan oleh peserta didik apabila guru mampu merencanakannya dengan porsi yang pas. Dalam hal ini, seorang guru sangat tidak diperkenankan untuk selalu menjadi subjek penyampaian materi yang memiliki kesan bahwa guru lebih aktif pada saat pembelajaran berlangsung. Peserta didik harus mendominasi pembelajaran di kelas agar pembelajaran lebih terlihat aktif, efektif, dan kondusif. Peran seorang guru selama proses pembelajaran adalah sebagai fasilitator, kedua mediator, dan ketiga motivator. Peran ini dapat mengembangkan sikap sosial, kognitif (psikologis), dan psikomotor.

Menurut Hartinah (Mujianto, 2019) mengemukakan bahwa pencapaian yang berhasil adalah melalui teamwork, kompetisi secara sehat, kemauan untuk berbagi, minat untuk diterima, memiliki sikap simpati, memiliki sikap empati, ketergantungan, persahabatan, keinginan yang bermanfaat, imitasi (tiruan), dan perilaku ketat. Perkembangan perasaan seperti ini hampir dapat dirasakan oleh peserta didik melalui kondisi lingkungan tempat tinggal, sosial ekonomi keluarga, lingkungan sekolah, kebudayaan masyarakat setempat, sistem nilai-nilai yang harus dilaksanakan atau dijauhi. Kemampuan menalar peserta didik dikemukakan oleh pandangan Piaget bahwa hakikatnya adalah kemampuan penalaran 
yang masuk akal. Peserta didik yang mampu mencapai kemampuan-kemampuan itu akan membentuk keterampilannya. Keterampilan yang terus diasah dan dipelajari sebagaimana mestinya akan menjadi suatu kebiasaan yang sangat baik bagi peserta didik.

Tugas seorang guru selain meningkatkan sikap sosial, kognitif, dan psikomotor dalam pembelajaran, guru tidak diperkenankan melupakan tugasnya untuk mengelola kelas dengan baik. Salah satu keterampilan mengajar yang sangat perlu dimiliki guru adalah keterampilan mengelola kelas (Menengah et al., 2019). Pengelolaan atau manajemen kelas harus direncanakan dengan sebaik-baiknya oleh seorang guru sebelum pembelajaran di mulai. Guru harus meciptakan iklim kelas dengan kondisi yang efektif. Diperkuat dengan pendapat Danim dan Danim (Toun, 2018) mengelola kelas harus mencakup segala hal, baik itu menciptakan iklim yang baik tetapi harus juga merangsang keterlibatan peserta didik ketika pembelajaran dikelas. Menurut (Wiyani, 2013) bahwa seorang guru harus menciptakan kondisi kelas (iklim kelas) yang sesuai sebagai berikut:

1. Guru memahami beberapa faktor yang ada di dalam kelas untuk membantu menciptakan kondisi yang berguna bagi peserta didik.
2. Guru mengetahui secara jelas perasalahan yang dapat diperkirakan sebelumnya agar tidak merusak iklim pembelajaran.

3. Guru mengetahui dan memahami pendekatan pengelolaan kelas.

Pembelajaran dapat dikatakan berhasil apabila guru mampu melakukan pengelolaan kelas dengan baik. Menurut Rofiq (Mujianto, 2019) mengemukakan manajemen kelas menunjukkan lebih pada kegiatan-kegiatan yang menciptakan dan melindungi kondisi yang maksimal bagi terjadinya proses belajar. Keterampilan guru dalam pengelolaan kelas akan berhasil apabila guru mampu menciptakan kegiatan di kelas melalui kerja kelompok. Selain menciptakan kondisi kelas yang kondusif dan efektif, guru harus membuat peserta didik untuk memiliki sikap yang disiplin. Pengelolaan kelas yang baik akan mewujudkan pembelajaran yang efektif (Suprianto et al., 2018). Guru dapat memberikan sebuah sinyal kepada peserta didik untuk terus memantau kegiatan peserta didik selama kegiatan pembejalaran.

Menurut Suharsimi (Eko Mauludin, Syamsiyati, 2013) menyebutkan bahwa pengelolaan merupakan penyelenggara yang dikelola agar berjalan dengan lancar, efektif, dan efisien. Pengelolaan merupakan sesuatu kegiatan yang bertujuan untuk menciptakan, memelihara dan mengembalikan iklim 
pembelajaran agar kembali efektif. Cara yang dapat dilakukan adalah dengan membuat tata tertib yang wajib untuk dipatuhi oleh peserta didik. Fungsi dari tata tertib ini adalah untuk menjaga keharmonisan antara pendidik dan peserta didik di lingkungan sekolah. Pengelolaan kelas dapat diartikan sebagai mendesain atau menjaga lingkungan sekolah, artinya guru harus mampu menciptakan lingkungan belajar seoptimal mungkin. Dengan demikian, peserta didik dapat mengikuti pembelajaran dengan baik dan tenang di dalam kelas. Proses ini dapat membantu menguatkan hubungan antara guru dan peserta didik dan pembelajaran yang terlaksana dapat berjalan dengan efektif. Adapun menurut E Mulyasa (Zahroh, 2015) pengelolaan kelas merupakan suatu keterampilan yang diciptakan oleh guru untuk menciptakan iklim belajar yang kondusif.

Dari pengertian pengelolaan tersebut, pengelolaan kelas merupakan sebagai usaha yang dilakukan oleh guru untuk menyediakan iklim atau kondisi pembelajaran agar lebih efektif dan lebih teratasi. Guru dapat berperan sebagai motivator untuk peserta didik agar mampu mencapai hasil belajar seperti yang telah diinginkan oleh peserta didik sebelumnya. Peserta didik yang baik memiliki semangat tinggi dalam belajar ataupun tidak, tugas utama seorang pendidik adalah untuk tetap memotivasi agar peserta didik lebih giat untuk belajar.

Pengelolaan kelas dapat dilakukan seorang guru untuk tujuan dapat membuat peserta didik memiliki sikap berani dan disiplin. Memiliki sikap yang berani terutama dalam mengemukakan pendapat, dapat membantu peserta didik untuk mengasah kemampuannya berbicara. Guru dapat memberikan penjelasan kepada peserta didik agar tidak merasa ragu pada saat mengemukakan pendapatnya. Guru memiliki peran untuk memberikan keyakinan kepada peserta didik bahwa keputusannya untuk mengemukakan pendapat merupakan "disiplin tegas" seperti yang dikemukakan oleh Lee Canter (Khalsa, 2008) menyebutkan hal ini sebagai "disiplin tegas" yang pada hakikatnya kombinasi penentuan pembatas dan pemberian pujian yang masuk akal jika mengikuti sebuah aturan.

Penelitian sebelumnya telah dilakukan oleh (Eko Mauludin, Syamsiyati, 2013) dengan judul "Korelasi Keterampilan Guru Mengelola Kelas Terhadap Hasil Belajar Siswa Kelas IV Pembelajaran Bahasa Indonesia". Hasil dari penelitian ini adalah dengan menerapkan pengelolaan kelas dengan baik, proses pembelajaran memiliki prosentase yang baik yaitu $77,65 \%$ yang dapat dikelompokkan baik. Rata-rata nilai yang diperoleh siswa adalah 78,48 atau sebesar 
6044. Nilai ini dikelompokkan baik oleh pendidik. Pada penelitian ini akan difokuskan peneliti menjadi dua subbab sebagai berikut.

(a) Bentuk pengelolaan kelas yang diolah guru guna meningkatkan keterampilan menulis. (b) Peran guru dalam pengelolaan kelas untuk mengembangkan keterampilan menulis pada pembelajaran Bahasa Indonesia.

Dengan demikian, proses pembelajaran melalui pengelolaan kelas akan berjalan dengan kondusif, lancar, efektif, dan efisien jika pengelolaan kelas sudat tepat. Ketepatan memilih cara untuk pengelolaan kelas sangat penting. Pada pengelolaan kelas, tugas utama guru adalah mampu untuk menguasai kondisi kelas terlebih dahulu. Guru dapat melihat kondisi tempat berlangsungnya di-laksanakan pembelajaran sudah memiliki kelayakan ataupun belum. Sebelum memulai pembelajaran, guru memberikan stimulus atau rangsangan kepada peserta didik untuk memberikan motivasi sebelum memulai pembelajaan. Berdasarkan uraian di atas, maka penelitian "Peranan Pengelolaan Kelas Dalam Mengembangkan Keterampilan Menulis di SMP Muhammadiyah 1 Malang" penting untuk dilakukan.

\section{METODE PENELITIAN}

\section{Lokasi dan Waktu Penelitian}

Penelitian ini menggunakan pendekatan deskriptif. Nawawi dalam (Eko Mauludin, Syamsiyati, 2013) memaparkan bahwa, pendekatan deskriptif merupakan suatu prosedur untuk memecahkan masalah yang dilakukan dengan cara penggambaran kondisi subjek atau objek penelitian, baik masyarakat ataupun lembaga berdasarkan realita. Jenis penelitian yang digunakan dalam penelitian ini adalah penelitian kualitatif, yaitu penelitian yang berlandaskan pada filsafat postpositivisme (Sugiono, 2017). Adapun menurut Moleong (Perbowo \& Pradipta, 2017) penelitian kualitatif merupakan suatu pendekatan dalam mengolah data mulai dari mereduksi, menyajikan, memverifikasi, dan menyimpulkan data. Adapun jenis penelitian ini digunakan untuk meneliti suatu kondisi yang dialami oleh objek dengan peneliti sebagai instrument kunci.

SMP Muhammadiyah 1 Malang merupakan sekolah menengah pertama yang ada di JL. Bridgen Slamet Riyadi No. 134, Oro-oro Dowo, Kec. Klojen , Kota Malang, Jawa Timur 65119. Sebagai sekolah pertama yang didirikan Muhammadiyah, SMP Muhammadiyah 1 Malang memiliki visi membantu peserta didik menjadi lulusan yang berilmu dan beragama. Adapun penelitiani ini dilaksanakan pada tanggal 11-15 November 2019, dalam kegiatan pembelajaran Bahasa Indonesia kelas IX dengan materi Teks Tanggapan. 


\section{Subjek Penelitian}

Menurut (Komariah, 2011) dalam penelitian kulitatif, subjek peneliti disebut sebagai informan. Informan yang terlibat dalam penelitian ini adalah peserta didik kelas IX di SMP Muhammadiyah 1 Malang kelas pada semester ganjil tahun ajaran 2019/2020. Jumlah peserta didik kelas IX ada 28 dengan jumlah lakilaki 16 dan perempuan 12. Karakteristik peserta didik kelas IX secara kemampuan merupakan kelas yang beragam. Masing-masing pesera didik memiliki kemampuan yang berbeda-beda.

\section{Teknik Pengumpulan Data}

Teknik pengumpulan data dilakukan untuk memperoleh data yang absah. Pada tahap pengumpulan data, peneliti melakukan beberapa cara untuk mengumpulkan data. Tahapantahapan yang dilakukan oleh peneliti adalah sebagai berikut. (a) Kegiatan peserta didik, (b) Guru yang sedang mengajar di dalam kelas, (c) Materi yang disampaikan oleh guru di kelas, (d) Media yang digunakan oleh guru, (e) Hasil pembelajaran yang telah disampaikan guru, (f) Kondisi lingkungan selama pembelajaran, (g) Wawancara dengan guru setelah pembelajaran berakhir. Dengan demikian, teknik pengumpulan data yang dilakukan oleh peneliti dilakukan pada saat pembelajaran berlangsung.

\section{Wawancara atau Interview}

Wawancara merupakan suatu metode atau cara yang dilakukan oleh peneliti untuk mengumpulkan data secara langsung melalui cara bertanya secara langsung kepada guru. Peneliti akan memberikan beberapa pertanyaan yang memungkinkan untuk mendapatkan data penelitian. Menurut (Komariah, 2011) wawancara didefinisikan sebagai teknik pengumpulan data untuk mendapat dan menggali informasi dari sumber data secara langsung.

\section{Dokumentasi}

Menurut (Sugiono, 2017) dokumen merupakan sebuah cacatan peristiwa yang sudah berlalu. Data hasil yang dikumpulkan berupa hasil atau karya tulisan dari peserta didik selama pembelajaran di dalam kelas. Berdasarkan data ini, dapat disimpulkan bahwa pengelolaan kelas atau manajemen kelas yang dibuat guru dalam meningkatkan keterampilan menulis peserta didik sudah berjalan sesuai dengan rencana guru atau tidak.

\section{Catatan Lapangan}

Catatan lapangan merupakan metode yang dipilih oleh peneliti untuk mengum-pulkan data dengan praktis dan lebih mudah untuk didapatkan. Pencatatan yang dimaksud adalah mencatat kegiatan pembelajaran di kelas. Beberapa hal yang perlu untuk dicatat mengacu pada aktivitas atau kegiatan guru dan peserta didik selama di dalam kelas sesuai dengan objek penelitian. 


\section{HASIL DAN PEMBAHASAN}

Bentuk pengelolaan kelas serta peran guru dalam mengelola kelas dapat dilihat melalui transkip data yang sudah didapatkan oleh penelitian dengan guru di SMP Muhammadiyah 1 Malang. Hasil yang didapat oleh peneliti digunakan sebagai penunjang untuk mengungkapkan bentuk serta peran guru dalam pengelolaan kelas. Hal inilah yang menjadi salah satu syarat keberhasilan guru dalam menciptakan kelas yang efektif. Berikut bentuk dan peran guru dalam pengelolaan kelas

\section{Bentuk Pengelolaan Kelas yang Diolah Guru guna Mengembangkan Ke- terampilan Menulis}

Guru Bahasa Indonesia di SMP Muhammadiyah 1 Malang dalam pem-belajaran keterampilan menulis menggunakan empat jenis bentuk pengelolaan kelas. Keempat bentuk pengelolaan tersebut digunakan oleh guru untuk meningkatkan keterampilan menulis peserta didik dan ke-empat bentuk tersebut dideskripsikan sebagai berikut.

\section{Pengelolaan Kelas Spatial Learning}

Pengelolaan kelas spatial learning dilaksanakan oleh guru untuk menyiapkan ruangan yang akan digunakan pada proses pembelajaran di dalam kelas. Proses realisasi pengelolaan kelas spatial learning yang dilaksanakan oleh guru dengan cara meminta peserta didik menata tempat duduk sebelum memulai pembelajaran. Dapat dilihat dari data di bawah ini.

Kalau ibu, di awal pembelajaran ibu selalu melihat kondisi ruang kelas terlebih dahulu aaa maksudnya kan itu hari rabu ya, biasanya sebelum mulai pembelajaran mereka ada jadwal mengaji bersama di masjid. Nah setelah itu mereka baru mulai masuk ke pembelajaran. Aaa tapi sebelum itu, biasanya ibu meminta mereka menata tempat duduk yang berantakan agar selama kegiatan belajar mereka merasa nyaman. Seperti itu.

Pada kata "selalu melihat kondisi ruang kelas" menjelaskan peran seorang pendidik sebelum memulai kegiatan pembelajaran. Langkah-langkah yang diambil oleh guru ini merupakan bentuk pengelolaan kelas yang diperuntukkan kepada peserta didik agar lebih siap untuk mengikuti kegiatan pembelajaran. 
Pengelolaan Kelas Determination of kekondusifan ruang kelas selama proses

\section{Regulation In The Room}

Pengelolaan kelas determination of regulation in the room atau penataan peraturan di dalam kelas oleh guru, dilakukan untuk menyiapkan kedisiplinan peserta didik selama mengikuti proses pembelajaran di dalam kelas. Proses realisasi ini dilakukan dengan cara memberikan aturan sederhana selama proses pembelajaran belangsung oleh guru. Dalam hal ini, guru memiliki kekuasaan memberikan sebuah aturan agar kondisi di dalam kelas tetap kondusif.

Biasanya aaa ibu sedikit memberikan peraturan agar mereka tetap kondusif selama pembelajaran. Ya ini supaya tidak menggangu yang lain ya. Terus ibu lebih jelas suaranya ketika menyampaikan materi. Biar paham gitu mereka dengan apa yang ibu sampaikan.

Kata "peraturan" mendeskripsikan pernyataan guru tentang peraturan atau sebuah tata tertib yang ada selama pembelajarannya sedang berlangsung. Peraturan berarti aturan yang wajib dan dilaksanakan oleh peserta didik, tidak dapat dilanggar atau dipatuhi. Peraturan ini dipergunakan oleh guru agar menjaga

\section{Pengelolaan Kelas Beginning Of Effective Teaching}

Pengelolaan kelas beginning of effective teaching atau permulaan pengajaran yang efektif yang dimulai oleh guru saat pembelajaran berlangsung, dilakukan agar memberikan hasil yang sesuai dengan yang direncanakan oleh guru. Keefektifan merupakan kunci yang dipegang guru sebelum memulai pembelajaran. Proses yang dilakukan oleh guru ini guru agar pengarajan yang efektif dapat terealisasikan dengan cara menyampaikan materi sesuai yang telah disiapkan dan merupakan lanjutan dari materi se-belumnya. Dalam hal ini guru harus benarbenar memperhatikan materi yang sebelumnya sudah disampaikan.

Mmmm itu ibu langsung memulai pembelajaran. Menyampaikan materi sesuai dengan KD dan Indikator yang ibu berikan. Karena ini juga masuk ke dalam keterampilan menulis, jadi nanti mereka akan menghasilkan tulisannya masing-masing.

Kata "materi sesuai" berhubungan dengan pengajaran yang efektif yang 
dipersiapkan guru pada awal memulai pembelajaran di dalam kelas. Dengan kata lain, penyesuaian materi sangat berpengaruh dengan keefektifan pembelajaran. Hal ini menunjukkan bahwa seorang guru memiliki peran yang penting terkait tercapainya keefektian pembelajaran di kelas.

\section{Pengelolaan Kelas Implementation of Effective.}

Pengelolaan kelas implementation of effective atau pelaksanaan pembelajaran yang efektif dilakukan guru dengan sebaik mungkin selama pembelajaran berlangsung. Pelaksanaan ini dilakukan agar pesan yang disampaikan oleh guru dapat dipahami oleh peserta didik dengan baik. Materi-materi yang disampaikan ini harus sudah sesuai dengan rancangan yang dibuat oleh guru sebelumnya.

Langkah-langkahnya ya mereka harus mendengarkan penjelasan ibu dari pertemuan-pertemuan sebelumnya, membaca buku yang mereka pilih, mendengarkan penjelasan terakhir sebelum menulis. Seperti itu saja. Kalau memang masih ada yang belum paham, mereka sangat diperbolehkan untuk bertanya.
Pada kata "mendengarkan penjelasan" memiliki hubungan dengan pelaksanaan pembelajaran efektif yang direncanakan oleh guru untuk proses pembelajaran. Mendengarkan berarti peserta didik memahami keseluruhan materi yang sudah disampaikan. Dengan kata lain, peserta didik yang berhasil mendengarkan materi yang disampaikan oleh guru dengan baik dapat membantu pelaksanaan pembelajaran menjadi lebih efektif sesuai dengan rencana yang dibuat oleh guru.

\section{Peran Guru dalam Pengelolaan Kelas untuk Mengembangkan Keterampilan Menulis pada Pembelajaran Bahasa Indonesia}

Pada bagian peran guru dalam pengelolaan kelas tersusun beberapa cara untuk mengembangkan keterampilan menulis peserta didik, terutama pada saat pembelajaran Bahasa Indonesia, agar pada setiap kompetensi dasar yang sudah diselesaikan dalam proses pembelajaran di kelas dapat menghasilkan sebuah karya atau hasil belajar yang ditentukan oleh guru, yaitu berupa sebuah tulisan. Kegiatan mengelola kelas yang dilakukan oleh guru SMP Muhammadiyah 1 Malang ada dua. Kedua cara yang dilakukan oleh itu adalah sebagai berikut.

\section{Mengelola Kelas Sebagai Lingkungan Belajar}

Peran terpenting seorang guru adalah mampu mengelola kelas menjadi lingkungan 
belajar yang menyenangkan serta nyaman. Peran ini dapat dilakukan oleh guru dengan cara memulai pembelajaran dengan membahas materi sebelumnya yang sudah dipelajari sebelum melanjutkan ke materi selanjutnya. Selain itu, guru dapat memberikan sebuah pengertian agar peserta didik tenang terutama pada saat guru menyampaikan materi. Hal ini dilakukan guru agar peserta didik dan guru merasa nyaman berada di dalam kelas selama pembelajaran berlangsung. Adanya kenyamanan ini akan membantu peserta didik lebih siap untuk menerima materi yang disampaikan oleh guru.

Baik, hari ini kita akan belajar untuk menulis. Tapi sebelumnya, ibu akan menjelaskan kembali materi pada pertemuan sebelumnya. Yaitu tentang struktur teks tanggapan. Ibu minta kalian semua tetap tenang selama ibu menjelaskan.

Kata "tetap tenang" menunjukkan peran guru dalam mengelola kelas, yaitu dengan mengendalikan peserta didik agar lebih nyaman di lingkungan belajarnya di dalam kelas. Kondisi seperti ini akan tetap dipertahankan oleh guru demi kenyamanan guru dan peserta didik itu sendiri selama pembelajaran. Menjelaskan kembali materi sebelumnya juga merupakan cara guru mengelola kelas sebagai lingkungan belajar. Hal ini dilakukan guru agar peserta didik dapat membuka memori mereka kembali dan membuat lingkungan belajar menjadi lebih bermanfaat bagi mereka.

Proses pengulangan materi sebelumnya dapat membantu peserta didik untuk memahami materi yang akan disampaikan oleh guru pada saat pembelajaran itu sedang berlangsung. Pemahaman ini dibuktikan oleh guru dengan cara meminta peserta didik untuk menulis teks tanggapan berdasarkan literasi yang peserta didik lakukan. Lingkungan belajar seperti ini akan sangat bermanfaat bagi peserta didik dan guru. Pengelolaan kelas yang dibuat oleh guru akan tercapai sesuai peran yang dilakukan selama pembelajaran.

Nah sekarang kalian diminta untuk menulis teks tanggapan. Yang dicari apa? Kalian kalau literasi itu membaca satu buku.

Pada kata "menulis" menunjukkan bahwa peran guru dalam mengelola lingkungan kelas berjalan dengan baik. Menulis dapat membatntu peserta didik memperkaya kata-kata melalui buku yang 
mereka baca. Dalam hal ini, peran guru adalah membantu peserta didik dalam kegiatan menulis. Lingkungan kelas harus diolah dengan sebaik mungkin agar peserta didik memahami tugas menulis yang diberikan oleh guru. Lingkungan kelas sangat berpengaruh terhadap imajinasi mereka untuk menuangkan isi yang ada dalam pikirannya menjadi tulisan yang menarik.

Aspek dari Lingkungan Kelas yang Perlu Diorganisasi

Peran guru selanjutnya untuk meningkatkan keterampilan menulis peserta didik adalah guru mampu mengorganisasikan lingkungan kelas dengan baik. Mengorganisasikan berarti guru berperan penuh dengan tingkah laku peserta didik di dalam kelas dan perilaku yang ditunjukkan guru kepada peserta didik harus mencerminkan layaknya seorang guru yang profesional. Aspek-aspek yang perlu diperhatikan oleh guru terpenting adalah kondisi tempat belajar. Peran guru di sini adalah harus menyesuaikan aspek-aspek yang perlu diorganisasikan dengan kondisi peserta didik. Pengorganisasian ini dilakukan agar peserta didik lebih aktif dan mampu berpikir kreatif.
Nah sekarang kalian ambil buku yang kalian baca ketika literasi.

$$
\text { Kata "ambil" merupakan }
$$
pengorganisasian yang dilakukan guru agar peserta didik lebih aktif dan antusias dengan buku yang sudah peserta didik baca. Dalam hal ini, guru dapat memerankan posisinya untuk membagi peserta didik menjadi beberapa bagian agar ketika mengambil buku di rak buku lebih teratur dan rapi. Hal ini juga dapat menghindari kegaduhan yang disebabkan karena teratur pada saat mengambil buku.

Peran guru selanjutnya yaitu mengorganisasikan peserta didik untuk memulai menulis. Sebelum itu, guru menjelaskan kepada peserta didik cara-cara menulis yang baik dan benar, bagian apa saja yang harus ada dalam tulisan tersebut dijelaskan sedetail mungkin oleh guru. Hal ini dapat dilihat pada data di bawah ini.

Kemudian ceritakan secara singkat buku ini. Kira-kira garis besarnya menceritakan tentang apa? Kemudian masuk ke sinopsis. Sinopsis kalau semisal kalian belum selesai membaca buku ini, sampai kalian yang aaa yang kalian baca. Ya. Misal kalian bacanya sampai halaman 50, kalian 
sinopsisnya sampai sesampainya

kalian.

Penjelasan guru terkait tugas untuk menulis teks tanggapan melalui buku yang sudah dibaca harus dipahami dengan baik oleh peserta didik. Peran guru di sini adalah, menjelaskan dengan sebaik-baiknya tentang tugas yang diberikan. Guru akan memberikan penjelasan lagi apabila peserta didik belum memahami, usaha seorang guru sangat diperhitungkan agar peserta didiknya paham. Guru sebagai pengatur lingkungan kelas juga harus menguasai cara-cara menjelaskan dengan baik agar mudah dipahami. Dari data di atas, peserta didik sudah memahami penjelasan yang disampaikan oleh guru. Dengan hal ini, peran guru dalam mengorganisasikan lingkungan kelas berjalan dengan baik.

Pengelolaan kelas atau manajemen kelas memiliki peran yang sangat penting terutama pada proses tercapainya hasil belajar. Guru memiliki peran untuk menciptakan lingkungan kelas yang kondusif dan lebih efektif lagi. Merencanakan kegiatan pembelajaran harus sesuai dengan rancangan pembelajaran yang sudah dibuat oleh guru. Selain itu dalam pengelolaan kelas, guru juga harus menjaga komunikasi dengan peserta didik selama pembelajaran berlangsung ataupun tidak. Komunikasi ini akan menjadi wadah tercapainya pengelolaan kelas yang dibuat oleh guru.

Bentuk pengelolaan kelas menjadi salah satu langkah yang digunakan oleh guru untuk membantu mengembangkan pengelolaan kelas yang dibuat agar tercapai dan mampu meningkatkan kemampuan belajar peserta didik di dalam kelas. Adapun (Afifi, 2014) menyebutkan bahwa terdapat beberapa bentuk pengelolaan kelas yang dapat digunakan guru. Terdapat lima bentuk pengelolaan kelas di antaranya pertama, pengelolaan Kelas Spatial Learning (Penataan Ruang Belajar), kedua, pengelolaan kelas determination of regulation in the room, ketiga, pengelolaan kelas beginning of effective teaching, keempat, pengelolaan kelas implementation of effective, dan kelima pengelolaan kelas study groups. Adapun dalam penelitian ini, dari kelima bentuk pengelolaan kelas hanya terdapat empat yang diperoleh melalui proses wawancara.

Pada dasarnya guru hanya dapat menentukan bentuk-bentuk pengelolaan kelas sesuai dengan kriteria dari peserta didik tanpa membedakan satu sama lain. Selain itu, guru perlu memperhatikan tentang prinsip penataan ruang kelas sesuai dengan bentuk pengelolaan kelas spatial learning dengan sebaik mungkin. Hal ini agar guru mampu 
mengawasi setiap gerak-gerik peserta didik selama proses pembelajaran berlangsung dan memastikan tidak ada ruang yang terlalu kosong agar tidak digunakan untuk bermainmain. Selain itu, terdapat peran penting yang dimiliki oleh guru dalam pengelolaan kelas. Adapun (Padmono, 2003) menyebutkan bahwa dalam perannya sebagai pengelola kelas, guru harus mampu mengelola kelas sebagai lingkungan belajar yang baik bagi peserta didik, aspek dari lingkungan sekolah yang perlu di organisasi, dan mengawasi kegiatan-kegiatan pendidikan. Dari pendapat yang dikemukakan oleh Padmono, peneliti menemukan data yang sesuai melalui obeservasi langsung di kelas.

Peran guru dalam pengelolaan kelas memiliki fungsi penting yakni berjalan dengan baik proses belajar di dalam kelas. Selain menentukan bentuk pengelolaan kelas, dalam penelitian ini juga memfokuskan peran guru secara langsung dalam pengelolaan kelas. Peran guru di sini adalah untuk membantu peserta didik agar memiliki sikap yang disiplin, teratur, mampu mengikuti kondisi lingkungan kelas dengan baik, dan partisipasinya dalam kegiatan belajar di dalam kelas (McDonald, ES \& Hershman, 2011)

Di dalam lingkungan kelas, terdapat banyak realita yang dialami oleh masingmasing peserta didi. Di sini peran guru sangat besar agar mampu mengorganisasikan lingkungan kelas agar dapat diterima oleh semua peserta didik dengan perasaan nyaman, keteraturan, disiplin, dan harmoni. Dari keempat perasaan tersebut, perasaan nyaman sangat dibutuhkan oleh peserta didik. Hal ini dikarenakan kenyamanan dapat membantu proses berpikir peserta didik lebih baik dan lebih memahami penjelasan materi yang akan atau telah disampaikan guru selama proses pembelajaran. Di dalam penelitian ini ditemukan dua peran guru yang memiliki keselarasan dengan kebutuhan peserta didik di dalam kelas.

\section{SIMPULAN}

Bentuk Pengelolaan Kelas yang Diolah Guru guna Mengembangkan Keterampilan Menulis

Guru menentukan bentuk pengelolaan kelas untuk meningkatkan keterampilan menulis peserta didik dalam pembelajaran Bahasa Indonesia. Bentuk-bentuk pengelolaan kelas yang digunakan oleh guru terdapat lima bentuk pengelolaan kelas di antaranya pertama, pengelolaan Kelas Spatial Learning (Penataan Ruang Belajar), kedua, pengelolaan kelas determination of regulation in the room, ketiga, pengelolaan kelas beginning of effective teaching, keempat, pengelolaan kelas implementation of effective, 
dan kelima pengelolaan kelas study groups. Adapun dalam penelitian ini terdapat empat bentuk yang sesuai dengan data yang diperoleh melalui proses wawancara dengan guru. Di antara keempat bentuk tersebut, guru benar-benar memfokuskan semua bentuk pengelolaan kelas dan diterapkan langsung di dalam kelas.

\section{Peran Guru dalam Pengelolaan Kelas untuk Mengembangkan Keterampilan} Menulis pada Pembelajaran Bahasa Indonesia

Guru berperan sangat penting dalam pengelolaan kelas terutama untuk meningkatkan keterampilan menulis peserta didik dalam pelajaran Bahasa Indonesia. Peran-peran pengelolaan kelas yang digunakan oleh guru terdapat tiga peran yaitu, mengelola kelas sebagai lingkungan belajar, aspek lingkungan sekolah yang perlu diorganisasi, dan mengawasi kegiatankegiatan pendidikan. Adapun dari ketiga peran tersebut, terdapat dua peran yang dilakukan guru berdasarkan hasil observasi langsung di dalam kelas. Diantara kedua peran tersebut guru menjalankan perannya sebagai pengelola kelas yang baik dan bertujuan membantu peserta didik untuk meningkatkan keterampilan menulis dengan cara mengelola kelas dengan baik dan memberikan peraturan yang wajib dipatuhi oleh setiap peserta didik. Fokus guru dalam perannya sebagai pengelola kelas dalam penelitian ini adalah memberikan kenyamanan selama proses pembelajaran berlangsung, mampu membentuk peserta didik agar lebih disiplin terhadap peraturan yang sudah dibuat oleh guru, mempertahankan kegiatan literasi yang sudah dibuat oleh guru, dan mengembangkan keterampilan menulis peserta didik.

\section{DAFTAR PUSTAKA}

Afifi, J. (2014). Inovasi-Inovasi Kreatif Manajemen Kelas dan Pengajaran Efektif.

Eko Mauludin, Syamsiyati, T. S. (2013). Korelasi Keterampilan Guru Mengelola Kelas Terhadap Hasil Belajar Siswa kelas IV Pembelajaran Bahasa Indonesia. Korelasi Keterampilan Guru Mengelola Kelas Terhadap Hasil Belajar Siswa Kelas IV Pembelajaran Bahasa Indonesia, 2(3), 1-17. file://C:/Users/LENOVO/Downloads/1 171-3766-1-PB.pdf

Khalsa. (2008). Pengajaran \& Disiplin Harga Diri. Indeks.

Komariah, D. S. dan A. (2011). Metode Penelitian Kualitatif. Alfabeta.

McDonald, ES \& Hershman, D. (2011). Guru dan Kelas Cemerlang.

Menengah, S., Negeri, P., Pinrang, S., \& Selatan, S. (2019). Peranan

Pengelolaan Kelas dalam 
Meningkatkan Motivasi Belajar Siswa

Pada Mata Pelajaran Bahasa Indonesia di Kelas IX SMP Negeri 1 Suppa

Kabupaten Pinrang Made Setoma. 1(2), 65-74. http://ejournal-

jp3.com/index.php/Pendidikan/article/vi ew/50/46

Mujianto, G. (2019). Strategi Pengelolaan

Kelas Dalam Menciptakan

Pembelajaran Literasi. Strategi

Pengelolaan Kelas Dalam Menciptakan Pembelajaran Literasi Yang Nyaman,

Aman, Tenang, Dan Menyenangkan, 175-176. http://research-

report.umm.ac.id/index.php/SENASBA

SA/article/view/2872

Padmono. (2003). Pendidikan Anak

Prasekolah.

Perbowo, K. S., \& Pradipta, T. R. (2017).

Pemetaan Kemampuan Pembuktian

Matematis Sebagai Prasyarat Mata

Kuliah Analisis Real Mahasiswa

Pendidikan Matematika. KALAMATIKA

Jurnal Pendidikan Matematika, 2(1),

81.

https://doi.org/10.22236/kalamatika.vol

2no1.2017pp81-90

Sugiono. (2017). Metode Penelitian

Kualitatif, Kuantitatif dan $R \& D$.

Penerbit Alfabeta.

Suprianto, S., Arhas, S. H., \& Salam, R.

(2018). Pengaruh Media Pembelajaran

dan Pengelolaan Kelas terhadap Prestasi

Belajar Siswa di SMK Negeri

Kecamatan Tanete Riattang, Kabupaten

Bone. Jurnal Ad'ministrare, 5(2), 137-

146.

https://ojs.unm.ac.id/administrare/article

/view/8162/4702
Toun, N. R. (2018). Jurnal Academia Praja Volume 1 Nomor 1 - Februari 2018. 1, 85-110.

https://ppjp.ulm.ac.id/journals/index.ph p/kog/article/view/1459/1170

Wiyani, N. A. (2013). Manajemen Kelas Teori dan Aplikasi untuk Menciptakan Kelas yang Kondusif. Ar-Ruzz Media.

Zahroh, L. (2015). Pendekatan Dalam Pengelolaan Kelas. Tasyri', 22, 175189.

http://ejournal.kopertais4.or.id/pantura/i ndex.php/tasyri/article/download/1550/ 1132 